\title{
Delimit Imagination? \\ A Comparison of Unabridged and Abridged Versions of Peter Pan
}

\author{
SCARLET P. W. LEE \\ ANNA W. B. TSO
}

\begin{abstract}
Adaptations of English literature have thrived in the last decade to cope with the ever-expanding market of teaching English. The reading public seems to endorse it as a pedagogic device to increase children's interest in reading and improve their language. Whether it has increased language proficiency remains a matter of debate. Our main concern, however, is the cultivation interest in literature through abridgement and to impact young learners' imagination. At first glance, abridgement seems to open the door to the world of the classics so that children may have first-hand experience of literature, yet to achieve its ultimate purpose one needs imagination vis-à-vis the reading text. Does the abridgement which favours less demanding verbal dexterity operate at the expense of children's imagination?

Pertaining to the question, we conducted a comparative study of J. M. Barrie's Peter Pan (1911), the unabridged version, and G. Clemen's abridged version (2000), their contexts and lexicons, in particular the deletion of some famous lines and passages, the replacement of some significant expressions and, eventually, how all these impact children's imagination. While it can be argued that the abridged text makes reading easier for learners, its characters have largely been flattened and the recurring theme of not growing up has been disparaged. The interplay of sexuality becomes banal. A visible example is the omission of the poignant start "All children, except one, grow up".

Our assertion is that abridgement should be executed and refined not only for the advantage of lightening the linguistic burden but, more importantly, of nurturing the imagination in the young minds. To unleash their imagination, light but purposeful and exuberant reading with a fine adjustment of authenticity and aesthetics is deemed necessary and beneficial. Ultimately, children will improve their language and develop a life-long interest in English literature.
\end{abstract}

Keywords: imagination, emotion, experience, psyche development, abridgement, education 


\section{Introduction}

Imagination, an innate mechanism of the human mind and once cursed as an unproductive way of thinking, has been gaining importance in education in the last few decades. The role imagination plays in pedagogy, in particular primary education, has been reviewed and advocated by scholars and educationalists. A favourable theoretical framework was established in that the young minds are seen more like a sponge - full of curiosity, craving for knowledge and ready to absorb it. Imagination serves as a buffer to bridge the inner world (the story) and the outside world (the reality), which unleashes the constraints and, with its engaging power, allows young readers to learn in a deeper, integrated, and sometimes faster way. This theory has been further applied to literature. Through reading, children are ushered into a world of imagination which indirectly guides them into a set of rules observed in a grown-up world. Yet, the sheer enjoyment of imagination through reading has been gradually replaced by purposeful reading in the last few decades. A burgeoning growth of abridgement of children's literature is seen to cater to the pedagogical needs mainly for young second language learners. Classic or popular novels are adapted to simpler versions through varying words, sentence structures and paragraphs, and are introduced to young learners in classroom. Though it has been purported that through teaching, pupils are encouraged to read literary works, which in turn cultivates their reading habits and benefits their integral growth, in addition to increased language proficiency, our proposition is that abridgement, if exercised indiscriminately, inhibits learners' imagination; hence it decreases its own educational value.

To shed light on the issue, we have conducted a comparative study of Peter Pan (1911) by J. M. Barrie and its abridged version (2000) by Gina D. B. Clemen. Peter Pan is a classic children's novel which appeared first as a short story in The Little White Bird (1902), not particularly intended for children, then was turned into Peter Pan, or The Boy Who Wouldn't Grow Up, a play staged in 1904, and eventually rewritten as a novel. It has achieved worldwide success over the last century and has been adapted to various genres such as film, cartoon and book. Book form adaptation is our grave concern, especially in an educational setting.

Research has suggested that imagination plays a significant role in stimulating learning among young readers. In Encyclopaedia of Primary Education, it is said, "[t] he power of imagination creates vision to empower and motivate children to act resolutely and achieve the desired goal, regardless of setbacks and disappointments" (Hayes 2010: 201). Imagination, as an innate vehicle, directs children's minds beyond consciousness, liberates them to make unconscious expressions which partially form individuation. It is 
Delimit Imagination? A Comparison of Unabridged and Abridged Versions of Peter Pan

crucial to psychic development as it nurtures their inner security and prepares children for adversity. Reading folktales, fantasy stories and mythology has become quintessential in the classroom and almost a compulsory subject in every school. Peter Pan is among other classic novels which are abridged to create suitable reading matter for children. Enriched with myths and fantasy, its abridged version does seem to promise a certain quality of imagination for children, yet, a closer look at the adaptation reveals something else. We were interested in probing into the influence of such abridgement on a young learner's imagination and its effects.

First, our research is based on a holistic view of education and imagination, inspired by the theories of Jung and Vygotsky, who postulate models to associate the two facets. We believe the perspectives they share can solidly form a fundamental principle underpinning in our study. We then proceed with an overview of Peter Pan, the original story written by J. M. Barrie in 1911. We shall then compare it to the abridged version, Gina Clemen in 2000, on the aspects of words, expressions and dialogues. Through exploring and comparing both works, an insight into the exploitation of abridgement will be reached. We agree that abridgement is significant in making classic novels easily accessible for children so as to cultivate a reading habit, a pre-requisite for successful language learning. Trimming words and expressions, simplifying sentence structures and varying paragraphs, if appropriate, can lessen burdens on reading. Yet, the precise extent to which they have to be exercised has posed questions. Should a novel be abridged at the expense of imagination? By exploiting abridgement, do we see reading as a means to an end rather than an engagement to benefit the learning process? As Matthews and Liu rightly put it - "how do we assist our students' adaptation to reality but at the same time give the inner world and its regulatory capacity the liberation it needs?" (2008: 19) It is our purpose, therefore, to pose these questions in the article and evaluate the role of abridgement in the context of education.

\section{Imagination and education}

Albert Einstein once said: "Imagination is everything. It is the preview of life's coming attractions." History has witnessed the power of imagination, for it is an indispensable tool for invention and advancement to propel human development. Likewise, more and more emphasis has been put on imagination in education in recent decades; whilst an increasing number of researches explore the importance of imagination in monitoring one's learning process, hence shaping the learners' mental growth. Among them are Jung and Vygotsky, the 
two exemplifiers who laid a significant theoretical framework for imagination and education.

One of Jungian theories which tie imagination to education is active imagination and individuation. He separates consciousness into directed functioning and non-directed functioning. Given the former's nature, which is more convergent, objective, close to modern acquisition, it helps children to acquire knowledge to adapt themselves to a more systematic and scientific world and is favoured in classroom learning today. Non-directed thought, on the other hand, touches a deeper mental stratum, i.e. our inner world, dissociates and liberates the repressed elements. Through imagination, the flow of images becomes active and purposeful.

[A]ctive imagination [...] means that the images have a life of their own and that the symbolic events develop according to their own logic [...] if your conscious reason does not interfere. (Jung 1935: para. 397)

It is the imagination that shapes individualism, makes our experience subjective, gives a sense of real self and ultimately achieves inner security. Its divergent effect also sets us free from the boundaries of the ego and gives us pleasure which motivates us to explore and subsequently assimilates the knowledge into our conceptual system. Had imagination not been activated, learning would remain superficial and the wholeness inside us would not be reached. From unreal to real, from unfamiliar to familiar, imagination makes unspoken experience possible for us, as Wilson rightly puts it, "[i] t is the imagination that goes to work on 'familiarizing' the terra incognita” (1962: xxiii).

From the perspective of education, imagination takes a dual role of defamiliarization and familiarization. Through reading folktales, stories of fantasy and the like, children are ushered to a strange land. Unfamiliar as it seems, children soon discover symbols of archetypes with the help of their imagination. The once unfamiliar objects now become familiar to them since they are the basic values shared in the collective unconscious. Such transformative journeys ultimately dispel the fear in children and deepen their sense of authenticity.

It is this incalculable value of imagination in education that has drawn support from Vygotsky, who dedicates a considerable part of his research to the field. He highlights the intricate link between experience and imagination:

[Imagination] becomes the means by which a person's experience is broadened, because he can imagine what he has not seen, can conceptualize something from another person's narration and description of what he himself has 
Delimit Imagination? A Comparison of Unabridged and Abridged Versions of Peter Pan

never directly experienced. He is not limited to the narrow circle and narrow boundaries of his own experience but can venture far beyond these boundaries, assimilating, with the help of his imagination someone else's historical or social experience. (Vygotsky 2004: 11)

In reality, a young learner may not know as much as an adult does, for all the experiences accumulated in the latter, but imagination takes a child beyond the boundary of consciousness to his inner world where common values shared by the collective unconscious are found and there the assimilation process operates and internalizes his experience. The mechanism echoes the critical stage underpinned in Jungian theories inasmuch as it helps complete a child's growth of his/her psyche. In education, children are empowered with imagination through reading. Words form images which children visualise through imagination and if assimilation is successful, they will become part of their inner selves and consolidate their life experience. To activate imagination, Vygotsky shares the common ground with Jung - "artistic images follow an internal logic of their own and this logic results from the relationships the work establishes between its own world and the external world" (2004: 18). A word, therefore, has to be successfully transformed into a mental image through imagination before the related concept or knowledge of the outside world is implanted in the learner's mind. This brings us to the key questions - how do we activate imagination through reading? Can an abridged version reach a similar effect to an unabridged one? To answer these questions, we have to look into the role of emotion as an affective feature in imagination as elucidated by Vygotsky.

In Imagination and Creativity in Childhood, Vygotsky establishes four tenets on the relations between imagination and reality, in which emotion appears as crucial in its dialectical influence on imagination. On the one hand, emotions combine with selected mental images to facilitate the mechanism of imagination and become internal expressions. On the other, imagination brings out emotions, hence external expressions. Emotion associates us with the fictitious roles in a story and affects our feelings empathetically. It enhances the experience embedded in our inner world.

The passions and fates of imaginary characters, their joys and sorrows move, disturb, and excite us, despite the fact that we know these are not real events, but rather the products of fantasy. This occurs only because the emotions that take hold of us from the artistic images on the pages of books or from the stage are completely real and we experience them truly, seriously, and deeply. (Vygotsky 2004: 14) 
LEE, TSO

In a story, words instead of illustrations activate our emotions and achieve the effect of assimilation. As a signifier, word connotes feelings and emotions, apart from its literal meanings. When words are combined into sentences and paragraphs, the connotations are even more poignant and subject to imagination, which ultimately shapes the experience and the psyche. Put into perspective, when a novel is abridged to make words simpler, sentences shorter, plot less intriguing, will the emotion carried by connotation lose its effect, thus trammelling imagination?

\section{Peter Pan}

Peter Pan as a hero. When Peter Pan was staged in theatre in 1904, it was an immediate success and garnered enormous attention from both literary and theatrical circles. Till today its popularity has extended globally, regardless of age and language. Its entrenched power lies in its protagonist, Peter Pan, who has been a household name over a century for his boyish, flamboyant and audacious charisma. His oft-cited line "To die will be an awfully big adventure" (Barrie 1911: 123) is captivating and enters every reader's mind. However, to see Peter Pan as a traditional hero will largely ignore the complex characters Barrie intends to portray - masculine and feminine.

First, the theme itself - the fight between Peter Pan and Captain Hook unarguably entails the elements of masculinity which stereotype a conventional hero. As the leader of all boys, he has to show courage, prowess, and to a certain extent, wittiness. The dialogues between Peter Pan and Hook aptly demonstrate these:

"So, Pan," said Hook at last, "this is all your doing."

"Ay, James Hook," came the stern answer, "it is all my doing."

"Proud and insolent youth," said Hook, "prepare to meet thy doom."

"Dark and sinister man,” Peter answered, "have at thee.” (Barrie 1911: 194)

His fearlessness marked in his famous oath "Hook or me this time" (Barrie 1911: 184) makes him an imposing figure in the story. Shorn of the camouflage, Peter Pan is a boy who craves love more than anyone but believes that he is rejected by his mother from the moment she closes the window, not letting him fly back into the room; whilst other boys who remain in the Neverland are just carelessly thrown off the prams. This longing for love not only makes him more pompous than the others but also very determined when Wendy tries to convince him to live with her family for fear of exposing his tender character 
Delimit Imagination? A Comparison of Unabridged and Abridged Versions of Peter Pan

once he is close to a real motherly figure. His avowal not to grow up and a strong desire to fly with Wendy and her descendants to the Neverland to fulfill the role, highlighted in the pithy line at the beginning of the story "ALL CHILDREN, EXCEPT ONE, grow up" (Barrie 1911: 1), speaks of the dilemma and the complexity of his character.

That Peter Pan has been engrossing readers in Barrie's world for a century is attributed to Barrie's creative use of words and expressions which not only spark off readers' imagination but leave an indelible impression. The famous line "Second to the right ... and then straight on till morning" (Barrie 1911: 31), the address of the Neverland, has exemplified the effect. The antithesis of a banal presentation of such daily topics grips the readers' attention, licenses them to freedoms of spatial imagination, eventually merging their world with Barrie's. When it comes to child readers, the process depicted is even more important to ignite their curiosity through questioning. Be it simple or difficult, the questions they ask and answers they receive ascertain children's active role as an audience of a literary work. Contrast to the traditional approach that requires children as passive readers to be lectured didactically and evangelically, Peter Pan offers them a brand new and refreshing experience in which we acknowledge the role of children as crucial participants to comprehend and interpret a story. As Thacker rightly puts it:

Literature, which arose out of this tradition, offered not only content based on fantasy and dream, but also a form based upon the expectations that children as listeners or readers possessed an unspoken understanding of the sublime and hidden meaning at the heart of the imaginative process. (2002: 16)

Captain Hook as a villain. Words dance on the paper, so do the characters. Throughout the century, Peter Pan has become the emblem of hedonic heroism. It is especially his pursuit of self-indulgence and heavenly freedoms, a stark contrast to earthly captivity, which has drawn admiration from all readers. His rival, Captain Hook, though a villain in the story, equally captures the readers' heart for his charisma. Like Peter Pan, Barrie never intends to make Hook a complete scoundrel because he has the same wish as Peter - longing for a mother. It is this unfulfilled wish that softens his masculine quality:

"Captain, is all well?" they asked timidly, but he answered with a hollow moan.

"He sighs," said Smee.

"He sighs again," said Starkey. 
"And yet a third time he sighs," said Smee.

"What's up, Captain?"

Then at last he spoke passionately.

"The game's up," he cried, "those boys have found a mother."

$[\ldots]$

There was a break in his voice, as if for a moment he recalled innocent days when - but he brushed away this weakness with his hook. (Barrie 1911: 113)

We are led to believe that throughout the battles, Peter and Hook do not fight for anything but a motherly figure, shadowy yet influential in their lives. The reminiscence further touches and brings back femininity long repressed, makes him susceptible to emotions, hence, gives rise to a tinge of romanticism. Likewise, when Peter kills Hook, his reaction is not celebratory but sentimental - "He had one of his dreams that night, and cried in his sleep for a long time, and Wendy held him tight" (Barrie 1911: 198). Barrie's depiction of the two protagonists, therefore, is multi-dimensional and of different magnitudes. They form the spine of the story and cannot be eliminated nor diminished, for the spirit of the story will utterly disappear.

Fairies as a sign of resistance against reason. The same emphatic position is held by the fairy Tinker Bell. Embellished as she may seem, Tinker Bell is, as Barrie puts it in Peter Pan, a "romantic figure" (1911: 37). She is symbolic of creativity, imagination and sentiments, a sign of resistance against "the force of rationalism, utilitarianism and repression" (Zipes 1979: 38) that dominated the lives of most Victorians during the rapid industrialization in Europe ${ }^{1}$. Much like other fairies Barrie has created, Tinker Bell symbolises fantasy and wild imagination in the story. Readers are informed that "[f]airies indeed are strange" (Barrie 1911: 85). Unless you are guided by childlike innocence, fairies are extremely difficult to see, especially when one sees only with adult

1 Having experienced much exploitation and suffering caused by the Industrial Revolution, the sudden growth of cities, and the dehumanizing rationalist utilitarian principles institutionalized by the bourgeoisie, Victorians, especially peasants and people of the lower classes, began to lose faith in the once highly-valued science, rationalism and empiricism. Romantic poets such as Samuel Taylor Coleridge, William Wordsworth and late Romantics like George MacDonald showed their resistance against logic and reason, the "normal filters of the imagination" (Manlove 1990: 145) through embracing and glorifying the female as a mystic symbol of imagination, irrationality and wisdom. It was believed that in the quest for truth, freedom and salvation, one must learn to relinquish one's exclusive reliance on logic and sight, break the barrier of the rational mind, and explore the deeper meaning of things through imagination, faith, the inexplicable and unspeakable. 
Delimit Imagination? A Comparison of Unabridged and Abridged Versions of Peter Pan

eyes. In chapter three, Wendy, who relies much on sight, finds Tinker Bell very hard to spot, "O Peter,... if she would only stand still and let me see her!" (Barrie 1911: 37) Swift, tiny and lofty, fairies are not restricted by our rational, scientific perceptions. They belong to what our eyes can't see, i.e. when most of us are bounded by sight and reason. Like a spark of inklings or a sudden flow of passion in the human mind, fairies are ever-changing, unpredictable and untraceable. One can only feel their presence if one can let go of adult perceptions, open up to imagination, and let the make-believe fill it freely.

The birth of fairies: the origin of imagination. Surprisingly, as the story unfolds, Barrie tells us that we are actually the creators of fairies. In chapter three, Peter Pan explains to Wendy about the beginning of fairies, "when the first baby laughed for the first time, its laugh broke into a thousand pieces, and they all went skipping about, and that was the beginning of fairies" (Barrie 1911: 35-36). This explanation of the birth of fairies can be interpreted symbolically - before the contamination of didactic and utilitarian training, we used to live at ease with imagination. We were once capable of enjoying the power of unconscious imagination comfortably and confidently. The departure from the world of imagination is a sign of growing up and innocence lost.

As Peter Pan tells us about the close bond between new babies and the power of imagination, he also reveals that when children grow up and develop rational thinking, they gradually lose their power of imagination and get dominated by what Tolkien (1947) called "observed fact" (Tolkien 1964: 44), causing the death of fairies:

You see children know such a lot now, they soon don't believe in fairies, and every time a child says, "I don't believe in fairies," there is a fairy somewhere that falls down dead. (Barrie 1911: 36)

From the feminist and ideological point-of-view, Kristeva's theory of the Semiotic (1980), an extension of the Imaginary of the Lacanian theory ${ }^{2}$, supple-

2 The Imaginary, according to Lacan, refers to the pre-Oedipal period when the child identifies himself with the mother and can make no distinction between him and the world outside. Similarly, the semiotic originates from the pre-mirror stage, when the child is still enjoying maternal pleasures in a dyadic unity with the mother. It exists before the formation of any binary oppositional structures, hierarchical forms of organization, distinctive boundaries, as well as the acquisition of a stable, unified subjectivity and identity (Grosz 1990: 43-44). The maternal body, in the form of nonverbal language and gesture, is the psychic "chora", the space that is the "receptacle, unnamable, improbable, hybrid, anterior to naming, to the one, to the father, and consequently maternally connoted" (Kristeva 1980: 133). In other words, the semiotic is the place where imagination begins. 
ments further understanding of imagination in Barrie's invention of fairies. It pertains to the development of imagination of a child - how, from the moment of birth, he gradually detaches himself from the maternal body where imagination originates (semiotic) and loses the imaginative power when growing up so as to conform to the order of the society. The ego, order, identity, consciousness, etc. intervene (Grosz 1990) and the child must learn to repress the semiotic so as to acquire the masculine discourse, namely the language that is commonly accepted, understood, and listened to. When he grows to rely more on logic, sight and reason, he loses touch with the natural and intimate bond with the maternal body and the semiotic. Imagination, stemmed from the semiotic, is therefore suppressed, ignored, forgotten and lost. Such purport on the disintegration of imagination is concurrent in Peter Pan, in which Barrie describes the loss of human power to comprehend the fairy language:

The loveliest tinkle as of golden bells answered him. It is the fairy language. You ordinary children can never hear it, but if you were to hear it you would know that you had heard it once before. (1911:29)

We used to be close to the unadulterated imagination when we were babies, but as we grew up and were detached from the maternal body, i.e. the source of imagination, innocence was lost and the once familiar language is now silenced. We are like Wendy and other ordinary children, who are dominated by reason, reality and social norms. When Wendy tries to listen to the sound of Tinker Bell, all she can hear is nothing more than "a tinkle of bells". Only Peter Pan, the child who never grows up, can communicate with fairies and translate the magical language for us:

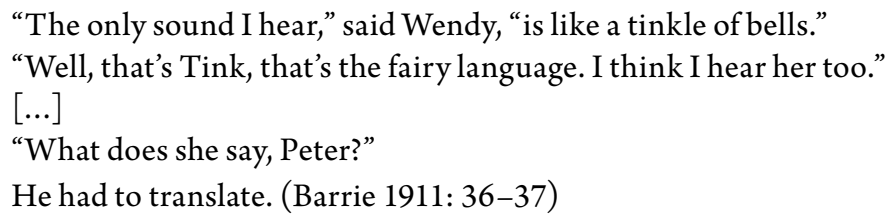

The magical language is a sign derived from the unconscious and carries arbitrary features. Once we acquire logic and reasoning skills, turn them into the main faculty to govern our speech and actions, the sign will turn into a symbol with designated and convergent meanings, further attached to the conscious. The lack of energy and depth into the unconscious degenerates imagination; causes the loss of abilities to comprehend the magical language. Peter Pan, nevertheless, decodes it, even translates it into a human language for Wendy, 
Delimit Imagination? A Comparison of Unabridged and Abridged Versions of Peter Pan

which is apparently due to his "eternity-in-between" (Kavey 2009: 79) and his penetration into the deepest stratum of mind which allows him to exercise free association and unbound imagination. Only when our symbolic order is unintentionally disrupted through dreams, slips of the tongue, slips of the pen, and various forms of inexpressibility can we rediscover real imagination. The use of fairy dust to denote the release of our ego and Peter Pan's imploring Wendy and others to "think lovely wonderful thoughts" (Barrie 1911: 45) obviously tell the readers about the significance of imagination.

Let go and fly: embracing the mystic power of imagination. " $[\mathrm{N}] \mathrm{o}$ one can fly unless the fairy dust has been blown on him" (Barrie 1911: 37). Indeed, logic and the rational mind tell us that human beings have no wings and they cannot fly like birds. Nevertheless, there are times when the semiotic may occasionally break loose - we let go of the symbolic and the overarching rational thinking but lure the power of imagination and irrationality into our dreams, silences and inexpressibility. Equally, the three children break through the mental barrier and fly into the sky with free will and the blessing of the fairy dust:

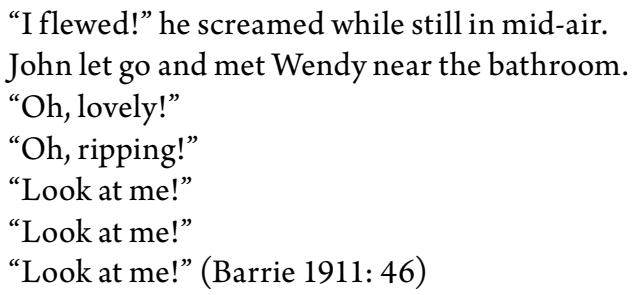

Excitement ruptures and affects readers through natural, uninterrupted, successive dialogues. Finally, they are able to unlock childhood wishes, impossible dreams, and their power of imagination that are restrained and long forgotten. This is when they truly enjoy the pleasure and the fruits of imagination, whereupon the legendary adventure embarks.

Close to the end of the story, when grown-up Wendy has lost all the power to fly, she sighs apologetically to Peter, "Peter...are you expecting me to fly away with you?... I can't come, I have forgotten how to fly" (Barrie 1911: 225). Wendy's heartrending revelation, though saddening readers, curtails children's unfettered fantasy and imagination. They are reminded of the truth that flying is almost improbable for ordinary people, for letting go of the symbolic order that we have been so used to and learning to embrace the sheer power of imagination is not as simple as we want it to be. What Barrie further shows is that between Wendy the child and Wendy the adult, there is the distinction between the child's primitive, liberating imagination and the adult's artificial, conditional imagination. Only by possessing the former can readers truly 
LEE, TSO

feel that they are flying like the characters. Yet, for most of us like the adult Wendy, the psychic chora which helps our childlike imagination flow cannot be reached by will, for it has been substituted by symbolic order which tells us that such imagination is difficult to grasp, uncontrollable and even dangerous.

The fairy rescue: a revival of faith and imagination. To Barrie, flying is only part of the imaginative experience. In chapter thirteen, "Do You Believe in Fairies?", Peter begs readers to rescue Tinker Bell, who is dying of poisoning. To save the fairy's life, readers must clap their hands to show that they believe in fairies:

"Do you believe?" he cried.

Tink sat up in bed almost briskly to listen to her fate.

She fancied she heard answers in the affirmative, and then again she wasn't sure.

"What do you think?" she asked Peter.

"If you believe," he shouted to them, "clap your hands; don't let Tink die."

Many clapped.

Some didn't.

A few beasts hissed. (Barrie 1911: 170-171)

Peter's urging, coupled with the third-person omniscience, is a powerful argument to convince us of the existence of the mythical world and of our keen participation as a crucial element to the plot development. He calls on readers to imagine without reserve, to act by heart. The reader-character interactions, enhanced under Barrie's third-person narrative voice, have created a world that successively draws us in and invites us to imagine the impossible.

\section{Between abridged and unabridged}

All children, except one, grow up. Any reader who has the slightest knowledge of Peter Pan would remember the line that starts the most captivating story ever: "ALL CHILDREN, EXCEPT ONE, grow up" (Barrie 1911: 1). It captures the great power and mystique necessary to form an imaginative world that transcends time and space, and is readily shared by any reader of any generation. Its recurring theme - to or not to grow up - dominates not only the story and the author's life but any of us. To Barrie's mind, the mundane topic never loses its charm and magic but has to be treated distinctively, challengingly and imaginatively, so that we are enticed to explore the issue with him with the utmost interest. As a prelude, the line emancipates our long repressed curiosity about the necessity of growing up, which, in Barrie's and his fictitious worlds, 
Delimit Imagination? A Comparison of Unabridged and Abridged Versions of Peter Pan

has been refused with grace and alacrity. To successfully enter the worlds, imagination has to be licensed to readers of any age including children, as Barrie fervently did in his life - making friends with children, reading and creating stories together. Though such a belief - to endorse the process of imagination in children - has been embraced in the abridged version, the fact is it is nullified through cutting the line at the beginning:

Wendy, John and Michael Darling live in a lovely house in London. They have got a big, sunny nursery. There are colourful pictures and a big clock on the wall. There are toys here and there. The Darlings are a happy family. Mr Darling and Mrs Darling love their children very much. Wendy is the first child, John is the second and Michael is the third. (Clemen 2000: 12)

Readers are not only made unaware of such a beautiful line but also introduced to the family background in a manner devoid of any idiosyncrasies penned by Barrie. The effect of stimulating readers' imagination to the subsequent happenings has been grossly diminished. Whilst it is deemed necessary for an abridged version to undergo significant cutting to lighten the lexical burden, to do so at the expense of the children's privilege of enjoying unbounded imagination does more harm than good. The theories propounded by Vygotsky and Jung make it unequivocal that imagination should be fostered as it is part of the mental and psychic development of a child. Any attempt to trespass on its use will hinder development, inflicting an excruciating reading pain upon the child. With such a predictable, unimaginative and action-less start, are they still interested to read on and for what purpose should they still read on?

Second to the right and then straight on till morning. Equally controversial is the deletion of the eccentric but indelible introduction of the address by Peter Pan to Wendy Darling:

She asked where he lived.

"Second to the right," said Peter, "and then straight on till morning."

"What a funny address!"

Peter had a sinking. For the first time he felt that perhaps it was a funny address. (Barrie 1911: 30-31)

The unusual address "Second to the right and then straight on till morning" (ib.) not only arouses Wendy's but any reader's curiosity. It extends our imagination far beyond our existential space, which is essential for putting ourselves into a dynamic and make-believe setting, and into the roles of mythical and 
LEE, TSO

folklore characters. We are left to grope our way from a nebulous entity to a visualised landscape, as if we were flying with the characters to the Neverland. Barrie's intention is not to let a name restrain our power of imagination but to liberate it with a short but lively description. Nevertheless, what is found in the abridged version does not arouse our interest in exploring nor amuse us heartily:

"Where do you live, Peter?" asks Wendy.

"I live in Neverland with the Lost Boys," says Peter. (Clemen 2000: 20)

We are prompted into a brief interlocution with a direct question and a flat-out answer. The notable delivery of the address is replaced by an immediate reply with the name, leaving no space for readers to ponder upon and uncover, not to mention the delicious conversation which characterises the liveliness and wittiness of Wendy and Peter. Tinges of a romantic link forged in the process of finding the Neverland and the relationship between Peter and Wendy have also vanished. Imagination and merriment present in Barrie's story for the words and ideas conducive to children's imaginative process has been deflated and become mind-numbing. Had the principle of abridgement - to render the readers' reading pleasure through spatial imagination - been upheld, it would have succeeded only partially, because the fundamental issues have not been fully addressed: has abridgement failed to recognize the real needs of child readers as active participants through imagination, or has it underestimated the hidden power of imagination and understanding in children as Thacker puts it?

To die will be an awfully big adventure. Notably, the epic line "To die will be an awfully big adventure" (Barrie 1911: 123) makes another remarkable impact on readers. In the middle of the story, as adventures unfold, Peter Pan finds himself in a dire situation and at this critical moment Barrie says:

Peter was not quite like other boys; but he was afraid at last. A tremour ran through him, like a shudder passing over the sea; but on the sea one shudder follows another till there are hundreds of them, and Peter felt just the one. Next moment he was standing erect on the rock again, with that smile on his face and a drum beating within him. It was saying, "To die will be an awfully big adventure." (Barrie 1911: 123)

This is a significant revelation about Peter's character. From the beginning of the story, we are told that Peter is a boy who hardly ever grows up, only has first teeth, and is the same size as Wendy. He is boyish, cocky and forgetful. All these make up the readers' general impressions of Peter until the moment when he faces real danger. His indomitable character is displayed unreservedly. 
Delimit Imagination? A Comparison of Unabridged and Abridged Versions of Peter Pan

His heroic reputation is truly established and evident in the eyes of the readers who would instantly be spellbound and in love with him, like Wendy, Tinker Bell, Tiger Lily and the mermaids on the lagoon. It is also this determined, exceedingly courageous character that marks him out among his peers, as Kavey observes:

[f] ear of death is not only a human characteristic; the prospect of impending doom will raise anxiety level in everything from mice to horses. But the ability to move beyond it and re-imagine death as an adventure, and even a potential escape from Neverland, and eternity in-between, is essentially human and remarkably boyish. (Kavey 2009: 78-79)

This uniqueness of Peter's mixed nature, underpinning and contributing significantly to the flow of the story; whilst constantly gripping the readers' attention, has, unfortunately, disappeared in the abridged version. Instead, a flattened one-dimensional Peter has been created with the cutting out of this particular line.

He sees a big kite with a long tail. It is flying slowly over the lagoon. He takes the tail of the kite and says, "Wendy, hold on to this tail and fly away with the kite." Wendy flies away.

"The sea is rising. I must fly away," Peter thinks.

When he gets home everyone is happy to see him especially Wendy. (Clemen 2000: 40)

The imagination we need to characterise Peter has become devalued. We are not invited to imagine how Peter alternates between humanness and boyishness because readers do not see such a need to interpret him as multi-dimensional, intertwining in the worlds as Barrie desires to show. The emotionless thought, "The sea is rising. I must fly away", utterly destroys the readers' enjoyment in the imaginative process to reach an animate, transparent and pronounced character that marks him as a timeless hero in the canon of children's literature. For young readers, such a sacrifice not only decelerates the process of understanding of human characters and the relationships in the real world but also the analytical skills acquired to deal with problems. Abridgement perpetually puts child readers into an innocent role, presuming and guarding their naivety and purity, by not dealing with ostensible taboos such as death, love or crime, that are in reality some of the most essential elements in developing a child's cognition and conscience in human relationships in the modern and complex world. The concrete idea that comes from a concrete world is thus 
censored to such an extent that not only does Peter, the hero, but also Peter Pan, the story, lose its appeal. Ultimately, what we find is a soulless Peter Pan in a dispassionate story with no imagination, the complete opposite of the unanimous agreement that "Barrie's works connect childhood to a time of limitless imagination” (Alton 2011: 38).

Un-fascinating fairies. In Clemen's abridged version, the resistance against the force of rationalism is absent. First and foremost, Peter Pan no longer shares with Wendy and the readers the mystic beginning and tragic death of fairies. In the same light, the reader-character interactive scene about rescuing Tinker Bell from dying is abruptly deleted. As a result, fairies are only loosely associated with, if not entirely detached from, Kristeva's notion of the semiotic.

Tinker Bell, who is supposed to be the symbol of irrationality and imagination in Barrie's version, is now made superficial as merely "a lovely fairy" (Clemen 2000: 18), sometimes "a bad fairy" (ib. 30). Nowhere in the abridged version is it mentioned that fairies are swift, mysterious and difficult to be spotted by the human eye, as in the original text:

It was not really a light; it made this light by flashing about so quickly, but when it came to rest for a second you say it was a fairy, no longer than your hand, but still growing. (Barrie 1911: 28)

It can be assumed that fairies are visible to all, both children and adults. The notion about how exclusive dependence on sight and reason limit imagination is again lost. More ironically, fairy language, the mysterious semiotic sound of silence that no ordinary people can understand, vanishes entirely from the abridged text. The need for translating fairy language is dismissed. It is as if anyone could communicate easily and efficiently with fairies without any problem. To readers, fairies from the Neverland become almost as common, apparent and uninteresting as any flat adult characters such as Mr and Mrs Darling.

In Clemen's abridgement, the only bond between fairies and fantasy is reflected through the fairy dust which is crucial to flying:

Wendy, John and Michael are very excited. They try to fly but fall on the beds and on the floor.

"No, no," says Peter. "Here is some fairy dust." He puts some fairy dust on their shoulders.

"Now try again," says Peter. 
Delimit Imagination? A Comparison of Unabridged and Abridged Versions of Peter Pan

"Look, I can fly!” says Wendy.

"I can too," says John.

“Me too," says little Michael. (Clemen 2000: 21-22)

Yet disappointingly, the adventurous experience of flying is also reduced to a skill that seems highly teachable, learnable and predictable. The text does not for once describe the difficulty and worries that Wendy, John and Michael encounter when flying with Peter Pan and Tinker Bell, nor does it mention to readers that ordinary people, when growing up, will lose the ability to fly even with the blessing of the fairy dust. Contrary to the unbound imagination encouraged by Barrie, we are discouraged to imagine flying and experiencing the emotions through such a unique experience. Adult will is consciously and intentionally applied to child readers through tailoring words and censoring ideas; hence, it blocks all the possibilities of fantastic imagination and only allows the superficial and harmless imagery to trail around their heads. The energy needed to push through the symbolic order to activate imagination, thus completing the process of internalization and self-actualization, is almost destroyed by the plain logic and order of language.

Worse still, readers are misled at the end when Mrs Darling tells Wendy she can visit Peter Pan in the Neverland regularly:

Mrs Darling says, "I have an idea. Wendy, you can visit Peter in Neverland every spring! You can stay there for a week."

"Can I really go to Neverland every spring, Mother?" asks Wendy.

Peter looks at Mrs Darling and asks, "Is that a promise?"

"Of course it is," says Mrs Darling. (Clemen 2000: 62)

The grown-ups' sorrow and grief at being too old to return to the Neverland is erased from the ending totally. The name "The Neverland" is deemed meaningless, for it has become an unimaginative place so easily reachable that one can visit it again and again in a particular season. Especially when compared to the ending of the original text which gives the readers an emotional rollercoaster:

Then she turned up the light, and Peter saw. He gave a cry of pain; and when the tall beautiful creature stooped to lift him in her arms he drew back sharply.

"What is it?" he cried again. 
LEE, TSO

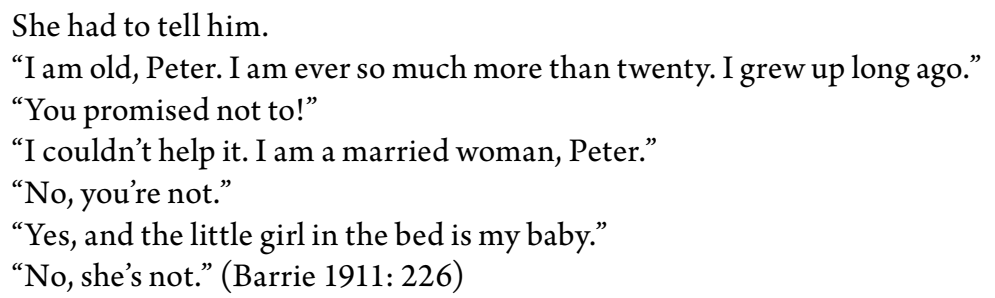

It is the struggling moment between Wendy and Peter that touches millions of readers' hearts, for Peter becomes a tragic figure who not only remains perpetually detached from reality but, more depressingly, from the central motherly figure, Wendy. We are brought to the saddest moment when Peter is deprived of the one wish that even immortal life cannot fulfil. Not only does Wendy go through the rite of passage but also Peter, who is humanised through beseeching. The Neverland seems to have lost its magic and we are for once made to believe that our joyous imagination has succumbed to order till, Peter finds Jane and other new mothers, "and thus it will go on, so long as children are gay and innocent and heartless" (Barrie 1911: 228). The ending re-ignites and prolongs our wild imagination in which Peter Pan, Tinker Bell, mermaids and the like will live in the Neverland ever after.

\section{Towards Abridged and Unabridged}

Considering the above, the glaring gap between the abridged and unabridged versions of Peter Pan in accentuating the imaginary space of young learners is obvious. Whilst we never cast doubt on the use of abridgement to open the door to the literary world for readers, we certainly do not want to see imagination dwindle. Imagination empowers us and readily places us in a literary text so that we can travel along with the characters in mind. We relate to them and learn from them not only through words and actions but experiences. While abridgement may lighten the learners' lexical burden, thus supporting the belief that reading can help in learning a language, it is important to remember that imagination per se is a key to integral learning. If an abridged text does not sufficiently stimulate the readers' imagination, they will no doubt find it hard to put themselves into the characters' roles, not to mention learning the language grudgingly. Assimilation and emotional development will not take place. Consequently, a much lesser effect will be seen on one's psychic growth as a whole, which Jung and Vygotsky defend vehemently. 
Delimit Imagination? A Comparison of Unabridged and Abridged Versions of Peter Pan

It is especially our great concern when it comes to such a powerful imaginative work as Peter Pan, in which J. M. Barrie devotes himself to imagining and sharing his world with generations, adults and children alike. As Zipes has said:

[I]magination is not only the necessary product of an individual's unfulfilled needs which are bound by static infantile sexual wishes for gratification, but it is socially and historically conditioned and embraces more than sexual desires. [...] Imagination is the organiser of meditation, in other words, the [mental] labour process through which natural drives, consciousness and the outer world are connected with one another [...] Hence, imagination is historical and changes; it can be used not only to compensate for what is lacking in reality but can be used in reality to supply practical criticism of oppressive conditions and the hope for surmounting them. (1979: 32)

Clemen's version of Peter Pan lacks qualities that would take readers into Barrie's imaginative world and explain the inexplicable. We are worried that it not only disrupts the order Barrie has set for his fictional world, but also the processes of reading for pleasure and psychic growth. Abridgement may, eventually, fail to fulfil its purpose when it is done unimaginatively. What we genuinely want is cautious abridgement to keep alive imagination.

\section{Scarlet Pui Wah Lee}

lee.scarlet@gmail.com

Via Gaetano Rappini 11

Roma, Lazio 00149

ITALIA

Anna Wing Bo Tso

atso@ouhk.edu.hk

A0729

The Open University of Hong Kong

30 Good Shepherd Street

Homantin, Kowloon

HONG KONG 
LEE, TSO

\section{References}

Alton, A. H., ed. 2011. Peter Pan. Ontario: Broadview.

Barrie, J. M. 2003. Peter Pan. NY: Aladdin Paperbacks.

Bettelheim, Bruno. 1976. The Uses of Enchantment: The Meaning and Importance of Fairy Tales. NY: Alfred A. Knopf.

Clemen, Gina D. B., ed., 2000. Peter Pan. Canterbury: Black Cat.

Collins, C. 1991. The Poetics of the Mind's Eye: Literature and the Psychology of Imagination. Philadelphia: Pennsylvania University Press.

Grosz, E. 1990. Sexual Subversion: Three French Feminists. Sydney: Allen and Unwin.

Hayes, D. 2010. Imagination. - Encyclopaedia of Primary Education. NY: Routledge, 201-202.

Hunt, P.; Lenz, M. 2011. Alterative Worlds in Fantasy Fiction. London: Continuum.

Jung, C. G. 1977. The Tavistock Lectures: On the Theory and Practice of Analytical Psychology. The Collected Works of C. G.. Jung. 18. Princeton, NJ: Princeton University Press.

Kavey, A.B. 2009. I do believe in fairies, I do, I do: The History and Epistemology of Peter Pan. - A. B. Kavey, L. D. Friedman, eds., Second Star to the Right: Peter Pan in the Popular Imagination. NJ: Rutgers University Press, 75-104.

Kristeva, J. 1980. Desire in Language: A Semiotic Approach to Literature and Art. NY: Columbia University Press.

Manlove, C. 1990. MacDonald and Kingsley: A Victorian Contrast. - W. Raeper, ed., The Golden Thread: Essays on George MacDonald. Edinburgh: Edinburgh University Press, 140-162.

Matthews, R. S.; Liu, H.C. 2008. Education and Imagination: A Synthesis of Jung and Vygotsky. - R. Jones et al., eds., Education and Imagination: Post-Jungian Perspectives. NY: Routledge, 15-37.

Papadopoulous, R. K., ed., 2006. The Handbook of Jungian Psychology: Theory, Practice and Applications. East Sussex: Routledge.

Rose, J. 1984. Peter Pan and Literature for the Child: Confusion of tongues. - The Impossibility of Children's Fiction. London: Macmillian, 66-86.

Thacker, D. C. 2002. Imagining the Child. - D. C. Thacker, J. Webb, eds., Introducing Children's Literature: from Romanticism to Postmodernism. London: Routledge, $13-25$.

Tidwell, J. C. 2009. Found Girls: J. M. Barrie's Peter \& Wendy and Jane Yolen's 'Lost Girls'. - S. R. Bobby, ed., Fairy Tales Reimagined: Essays on new retellings. Jefferson, North Carolina: McFarland \& Company, 58-67.

Tolkien, J. R. R. 1964. On fairy stories. - J. R. R. Tolkien, Tree and Leaf. London: Allen and Unwin.

Vygotsky, L. S. 2004. Imagination and Creativity in Childhood. - Journal of Russian and East European Psychology, 42 (1), 7-97.

White, D. R.; Tarr, C. A., eds., 2006. J. M. Barrie's In and Out of Time: A Children's Classic at 100. Lanham, Md.: Scarecrow Press. 
Delimit Imagination? A Comparison of Unabridged and Abridged Versions of Peter Pan

Wilson, C. 1962. The Strength to Dream: Literature and the Imagination. London: Gollancz.

Zipes, J. 1979. Breaking the Magic Spell: Radical Theories of Folk and Fairy Tales. London: Heinemann. 